\section{Ubiquitous euphorbia is anything but euphoria for the eye: a reminder to get any area of contact with the toxic sap under the tap}

Eye (2018) 32, 243-247; doi:10.1038/eye.2017.204; publlished online 22 September 2017

The minimally inflamed eye associated with severe pain. Gardening history. Little to see clinically? Think euphorbia. As an ST7 in Ophthalmology, I felt unnerved when a patient presented with an excruciatingly painful eye and minimal history. She reported gardening but denied use of any chemicals, foreign bodies or trauma. I was unable to explain the severity of the pain in the context of $6 / 9$ snellen acuity, minimal punctate changes and mild conjunctival inflammation. $\mathrm{pH}$ was normal and equal, no intraocular changes, a normal intraocular pressure and an absence of a foreign body. The eye was irrigated, preservative-free chloramphenicol and lubricants commenced, in addition to short-term topical anaesthetic use after ruling out any infection. The eye improved over the following days.

Subsequent clinical discussion took place with several colleagues before euphorbia was suggested. The patient was contacted to assess the clinical status and implore about the possibility of euphorbia in the garden. After scouring the garden, the presence of euphorbia lathyrsis (caper spurge) was identified. (Figure 1: Euphorbia Lathyrsis (caper spurge)).

This species has previously been associated with alkali chemical injury and extreme pain. ${ }^{1}$ Given its common use as ornamental houseplant and its presentation as a weed in UK gardens, this discussion aims to increase awareness among medical staff, nurses and gardeners and act as a reminder to implore about gardening history.
Euphorbia is a genus of plants in the Euphorbiaceae family. At least 2100 species are recognised and it is one of the most diverse groups of flowering groups on earth. ${ }^{2}$ At least twenty-one species are recognised in the United Kingdom. ${ }^{3}$ All varieties of euphorbia produce a whitish latex sap upon being cut. The sap extruded is often toxic. ${ }^{2}$ However, the toxicity varies between and within genera. ${ }^{4}$ The caustic nature of the sap has been taken advantage of medically, aiding wart removal since the ancient Greek times. ${ }^{5}$ Its historic use in treating tumours, carbuncles, gangrenes, fistulas and even pterygia have also been noted. ${ }^{6}$ More recent science has demonstrated that the sap contains a diterpenoid diester with an antineoplastic activity in rodents. ${ }^{6}$

Although pain following ocular contact tends to be severe enough to result in blepharospasm and vomiting, witnessed in this case and noted previously, ocular signs tend to be minimal and sequalae do not commonly result.7,8 Presentation is with severe burning, photophobia, epiphora and a moderate reduction in Snellen acuity of 1-2 lines. Commonly examination findings include a mild keratitis and conjunctivitis, with or without a mild anterior uveitis, followed by epithelial sloughing, regeneration and complete resolution. ${ }^{6-11}$

More severe ocular reactions have also been reported, including severe conjunctival burns, raised intraocular pressure, severe keratitis, keratouveitis and stromal oedema. A hypopyon has been noted in 3 cases and an alkali chemical injury noted in two and presumably a third where conjunctival burns were noted. $4,9,11-14$ There is risk of corneal ulceration and there have been several case reports of subsequent blindness. ${ }^{6,8}$ One case resulted in a dense 


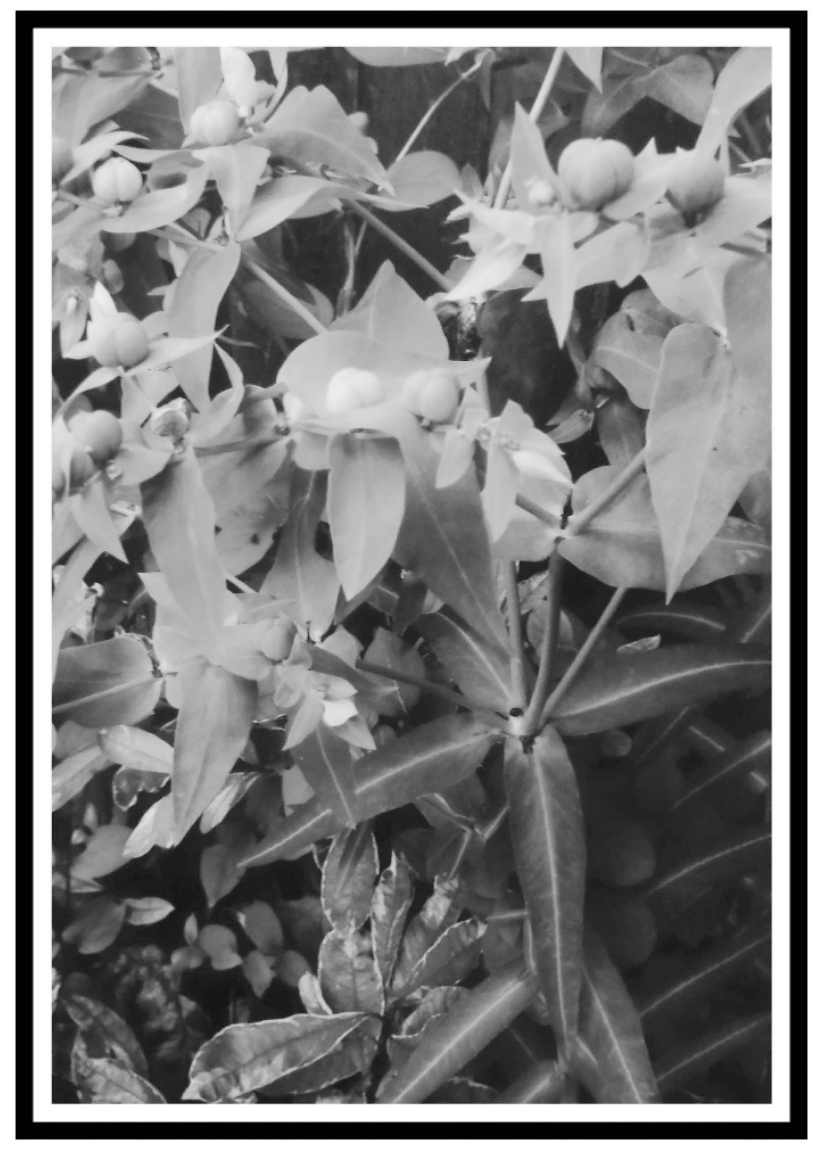

Figure 1 Euphorbia Lathyrsis (caper spurge).

corneal opacity requiring penetrating keratoplasty. ${ }^{15}$ A further case resulted in end-stage limbal stem cell deficiency requiring a Boston keratoprothesis following exposure to euphorbia latex. ${ }^{16}$

The toxicity of euphorbia varies with the species of plant. ${ }^{9}$ A clinical presentation according to plant species has been discussed by Eke et al, who agree the degree of inflammation is related to the type of euphorbia as well as the quantity of sap making contact with the eye. ${ }^{8}$

- Petty spurge (E peplus) sap: causes typical keratopathy with a fibrinous anterior uveitis.

- Caper spurge (E lathyris) sap: similar clinical picture, with a less severe uveitis without fibrin.

- The pencil tree (E tirucalli) and candelabra cactus (E lactea): keratopathy with a variable degree of uveitis.

- E characias and its subspecies wulfenii: mild keratopathy without uveitis. ${ }^{8}$

Although treatment remains largely empirical, it is safe to treat this scenario as an alkali injury, commencing thorough topical irrigation regardless of the $\mathrm{pH}$ or evidence of foreign body. ${ }^{9,10}$ Supportive measures can be commenced, including lubricants, prophalytic topical antibiotic, eye patching and pressure pad or a bandage contact lens. Topical steroid use is debatable but given that the greatest morbidity is associated with secondary infections, it may be wise to avoid steroid use. ${ }^{9}$

Caring for euphorbia plants varies, but all require pruning. Some evergreen varieties should only have the blooms cut back after flowering, whereas others have biennial stems which need cutting to the ground. Deciduous euphorbias need cut to the ground in the autumn. ${ }^{17}$ Gloves and eyewear protection are recommended when handling this plant alongside awareness to avoid ocular contact.

Care should also be taken with children in the vicinity, keeping all hazardous species away from places children are likely to eat or touch them. Although 99\% of UK plants are not dangerous, and poisonings are rare, extreme symptoms such as drowsiness, nausea and vomiting or extreme pain warrant a medical review. It is advised that a sample of any suspected plant is brought for identification. ${ }^{18}$

The Horticultural Trades Association (HTA) produced a 'Code of Practice for Potentially Harmful Plants', placing harmful plants into 3 categories (applied below). ${ }^{19}$

A. Most harmful includes only poison ivy/oak, which is poisonous if eaten and associated with severe blistering dermatitis.

B. Plants toxic when ingested and irritant to the skin and eyes.

C. Plants harmful when eaten and irritant to the skin and eyes.

Other UK plants that are skin but not eye irritants include the parsnip plant, stinging nettles, chrysanthemums (C), leyland crypress (C), peruvian lily, rue sap (B), fig sap (C), burning bush sap (C) and hogweed sap (B). Other common plants poisonous when ingested include the yew (B), daffodil bulbs (C), delphinium (C), laburnum (B), autumn crocus (B), galanthus snowdrops, cherry laurel (seeds and fruit) (C), rhubarb leaves, stinkweed (B), angel's trumpets (B) and henbane (B). The most poisonous UK plants associated with fatality include the foxglove (B), deadly nightshade (B), cuckoo-pint (B), hemlock water dropwort, wild hyacinth (C), lily of the valley (B) and mistletoe berries. Figure 2 depicts common plants which are irritant or toxic to the skin or eyes. ${ }^{19-23}$ 
Further information:

- National Poisons Information Service: https://www. toxbase.org; mail@toxbase.org; Tel: UK 03448920111 Ireland (01)8092566.
- Royal Horticultural Society Gardening Advice Tel: (0845)2608000.

- https://hta.org.uk/resourceLibrary/code-of-practicefor-potentially-harmful-plants.html.

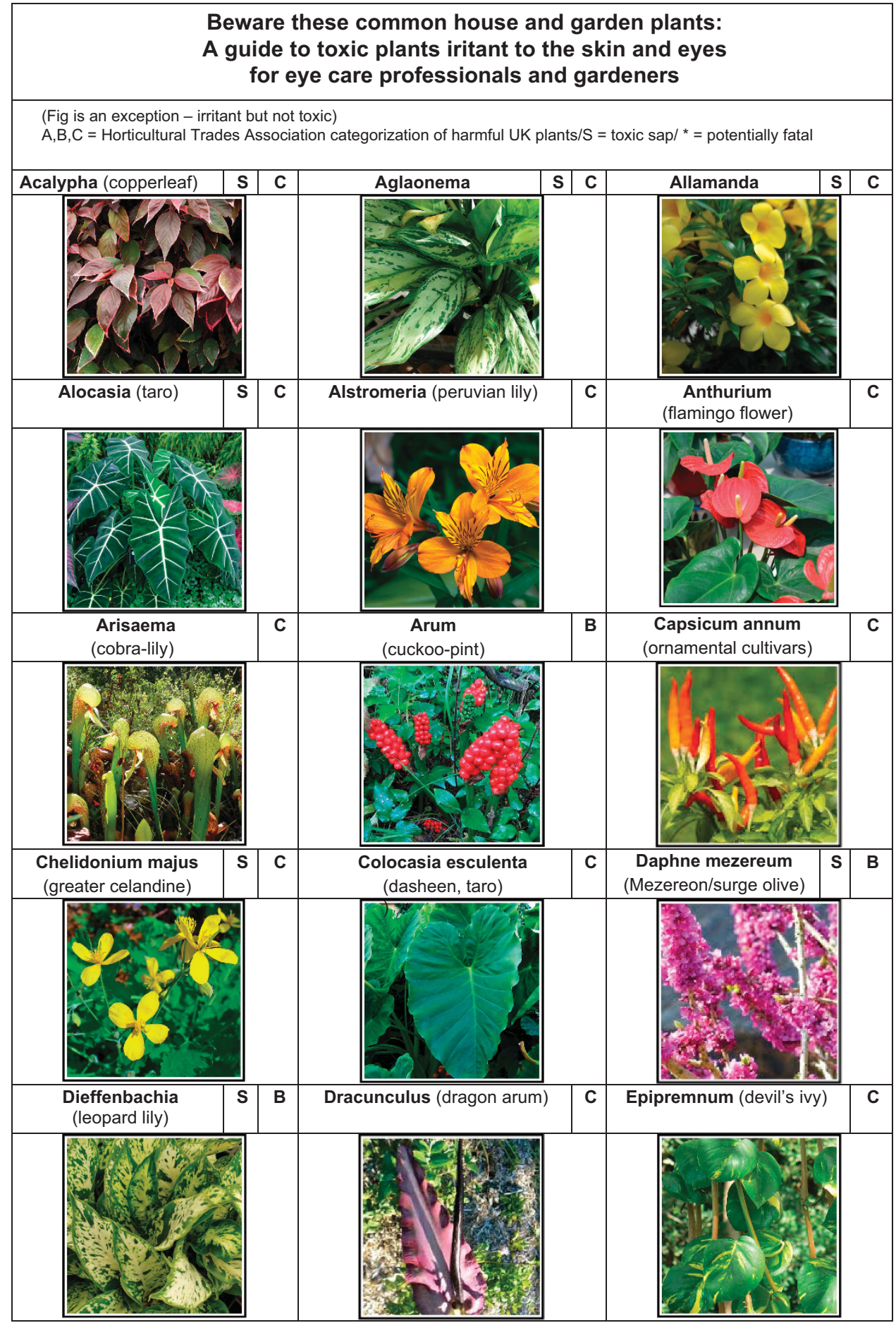

Figure 2 A guide to toxic UK plants for eye care professionals and gardeners. 


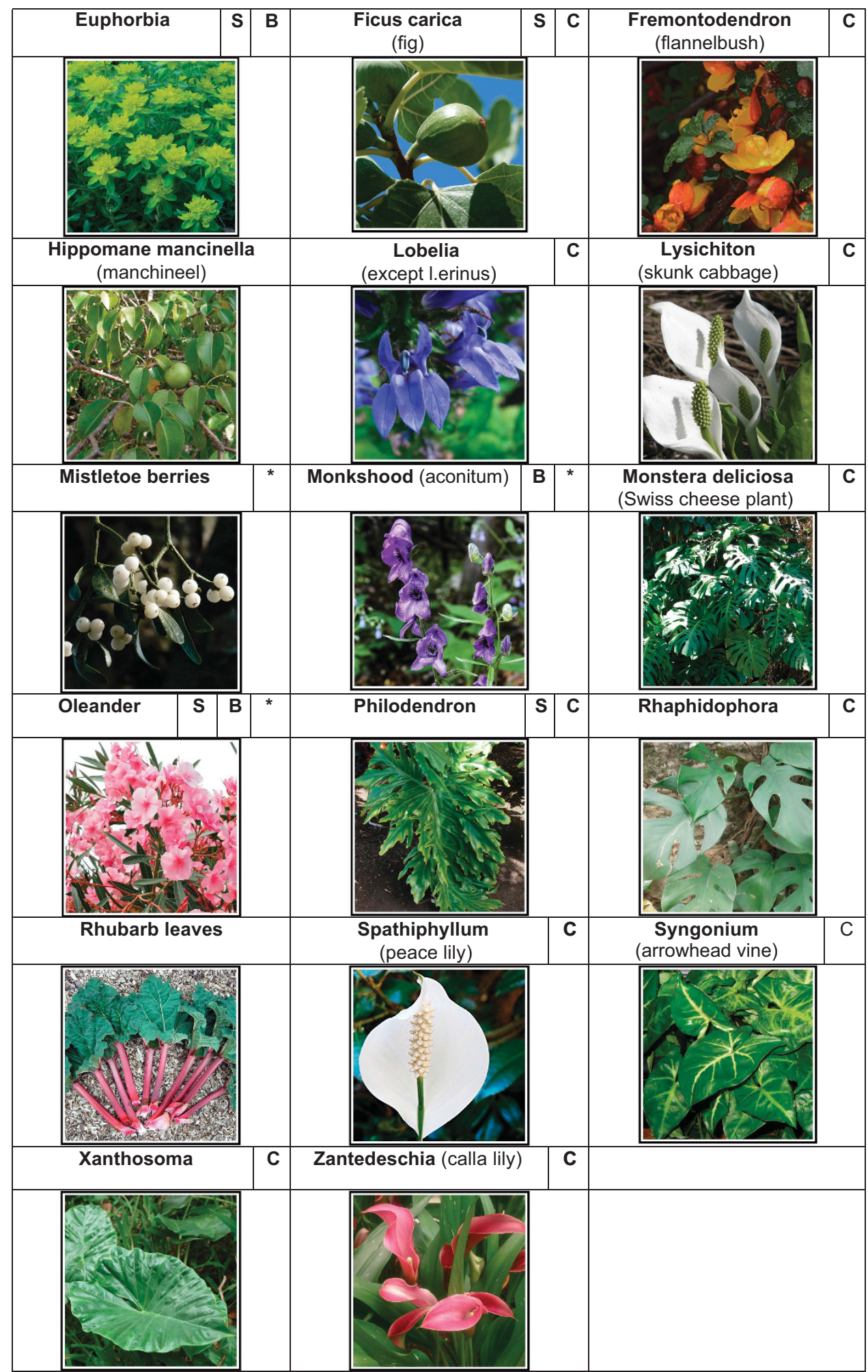

Figure 2 (continued). 


\section{Conflict of interest}

The author declares no conflict of interest.

\section{References}

1 Ioannidis AS, Papageorgiou KI, Andreou PS. Exposure to Euphorbia lathyris latex resulting in alkaline chemical injury: a case report. J Med Case Reports 2009; 3: 115.

2 About the genus Euphorbia [Internet]. [Cited 8 August 2017]. Available from: http://www.euphorbiaceae.org/ pages/about_euphorbia.html.

3 Stace C. New flora of the British Isles. Cambridge University Press: Cambridge, $1991: 545$.

4 Lisch K, Klin Monbl. Augenheilkd. The effect of the sap of Euphorbiaceae on the eye. [Article in German] 1980; 176(3): 469-471.

5 Eke T. Acute kerato-uveitis associated with topical self-administration of the sap of the Petty Spurge (Euphorbia peplus). Eye (Lond) 1994; 8(Pt 6): 694-696.

6 Scott IU, Karp CL. Euphorbia sap keratopathy: four cases and a possible pathogenic mechanism. Br J Ophthalmol 1996; 80(9): 823-826.

7 Alexander S Ioannidis, Konstantinos I Papageorgiou, Petros S Andreou. Exposure to Euphorbia lathyris latex resulting in alkaline chemical injury: a case report. J Med Case Reports 2009; 3: 115.

8 Eke T, Al-Husainy S, Raynor MK. The spectrum of ocular inflammation caused by euphorbia plant sap. Arch Ophthalmol. 2000; 118(1): 13-26.

9 Fleischman D, Meyer JJ, Fowler WC. Keratouveitis from Euphorbia cyparissias exposure is a temporal phenomenon. Clin Ophthalmol 2012; 6: 851-853.

10 Antcliff RJ, Hodgkins PR, Bowman R, Keast-Butler J. Euphorbia lathyris latex keratoconjunctivitis. Eye (Lond) 1994; 8(Pt 6): 696-698.

11 Basak SK, Bakshi PK, Basu S, Basak S. Indian J Ophthalmol. Keratouveitis caused by Euphorbia plant sap 2009; 57(4): 311-313.

12 Amissah-Arthur KN, Groppe M. Beware the ornamental plant. Emerg Med J. 2010; 27(8): 647.

13 Merani R, Sa-Ngiampornpanit T, Kerdraon Y, Billson F, McClellan KA. Cornea. Euphorbia lactea sap keratouveitis: case report and review of the literature 2007; 26(6): 749-752.
14 Ioannidis AS, Papageorgiou KI, Andreou PS. Exposure to Euphorbia lathyris latex resulting in alkaline chemical injury: a case report. J Med Case Rep 2009; 3: 115.

15 Dutta J, Choudhury S, Lahiri K, Savale S, Banerjee M, Datta H. Penetrating keratoplasty restoring vision in an unusual case of corneal opacity following exposure to Euphorbia latex. Trop Doct 2015; 45(4): 239-240.

16 Dutta J, Mukhopadhyay S, Datta H, Sen S. Boston keratoprosthesis restoring vision in an unusual case of end-stage limbal stem cell deficiency following exposure to Euphorbia latex. Int Ophthalmol 2012; 32(1): 77-79.

17 Gardeners World [Internet]. [Cited 8 August 2017]. Available from: http:/ / www.gardenersworld.com/plants/ plant-inspiration/pruning-euphorbias/.

18 Telegraph everything in the garden isn't lovely [Internet]. [Cited 8 August 2017]. Available from: http://www. telegraph.co.uk/news/health/3317230/Everything-in-thegarden-isnt-lovely.html.

19 The Horticultural Trades Association (HTA) Code of Practice for Potentially Harmful Plants [Internet]. [Cited 15 August 2017]. Available from: https://hta.org.uk/resourceLibrary/ code-of-practice-for-potentially-harmful-plants.html.

20 Royal Horticultural Society: Potentially harmful garden plants [Internet]. [Cited 15 August 2017]. Available from: https: / / www.rhs.org.uk/advice/profile?pid $=524$.

21 Real Gardeners: Irritant plants [Internet]. [Cited 15 August 2017]. Available from: http://www.realgardeners.co.uk/ irritantplants.htm.

22 NHS choices Livewell: Plant dangers in the garden and countryside [Internet]. [Cited 15 August 2017]. Available from: http:/ / www.nhs.uk/Livewell/bites-and-stings/ Pages/Plant-dangers-garden-countryside.aspx.

23 IFLScience: Meet five of the UK's most poisonous plants [Internet]. [Cited 15 August 2017]. Available from: http:// www.iflscience.com/plants-and-animals/meet-five-uk-smost-poisonous-plants/.

K McVeigh

Ophthalmology Fellow, Bristol Eye Hospital, Bristol, UK

Correspondence: K McVeigh, Ophthalmology Fellow, Bristol Eye Hospital, Bristol BS1 2LX, UK Tel: 07971262818. E-mail: katherine.mcveigh@nhs.net 